\title{
¿EXPULSAR DE NUEVO AL POETA? DE ARTE Y POLÍTICA EN NIETZSCHE ${ }^{1}$
}

\author{
Manuel Barrios Casares
}

Universidad de Sevilla

RESUMEN: El reproche de «esteticismo político», empleado por algunos intérpretes para descalificar la filosofía de Nietzsche, sugiere la equívoca idea de que es la intrusión de una perspectiva procedente del terreno del arte en el campo de la política lo que ha conferido un sesgo conservador a dicho pensamiento. Se discute aquí este enfoque, tomando como eje central del análisis la polémica de Nietzsche con Wagner.

Palabras clave: arte - política - poeta

ABSTRACT: The charge of "political aestheticism», brought by some interpreters to discredit Nietzsche's philosophy, suggests the misleading idea that it is the intrusion of a perspective derived from the field of the arts into the sphere of politics that has conferred a conservative bias to this thought. This paper discusses this approach, taking as the crux of the analysis the controversy between Nietzsche and Wagner.

Keywords: art - politics - poet

De Nietzsche cabe decir en todos los sentidos que fue un soberbio malentendido. Pocos pensadores han paseado con tan enamorada pasión de la distancia por las cumbres y abismos que marcan las lindes de nuestra civilización, avistando, en el horizonte finisecular del siglo XIX, esa experiencia de vaciado de mundo y falta de fundamento último de la existencia que él acertó a caracterizar en términos de una vivencia histórica de la muerte de Dios. Precisamente por ello, pocos han sufrido una deformación tan intensa de su pensamiento por parte de toda clase de maniobras exegéticas, empeñadas en actualizar y dotar de rendimiento efectivo inmediato a las grandes ideas-límite, a los enormes interrogantes planteados por él. Pero la fuerza y la audacia de este pensador intempestivo, que durante las primeras décadas del siglo xx, en medio de las más agudas y dramáticas formulaciones de la crisis de la Modernidad, cautivó a figuras tan diversas como Georg Simmel, Max Weber, Thomas Mann, Hermann Hesse, Ernst Jünger, Martin Heidegger, Karl Jaspers o Gottfried Benn, permanece inalterable a inicios de este milenio.

1. El presente texto corresponde a la conferencia preparada para el curso de verano de la Universidad Complutense de Madrid De la ciudad, los poetas y los dioses: el otro Nietzsche, dirigido por los profesores Juan Manuel Navarro Cordón y Eugenio Fernández García en el año 2002. 
¿Cómo asimilar a alguien tan distinto? ¿Cómo diluir en el contexto de la demagógica moral de rebaño y pensamiento único que reina por doquier su sentimiento aristocrático de la vida? ¿Cómo incorporar el dictamen de quien apreció síntomas de nihilismo y decadencia en los más elevados valores de Occidente? ¿Cómo digerir a alguien que dijo de sí, y que tal vez no se equivocó: «Conozco mi suerte. Algún día irá unido a mi nombre el recuerdo de algo gigantesco, - de una crisis como jamás la ha habido en la tierra, de la más profunda colisión de conciencia»? ¿Cómo soportar, en fin, a un individuo que se entretuvo en explicarnos por qué era tan sabio y escribía tan buenos libros?

Casi siempre mediante el fácil etiquetado de su osadía intelectual sin precedentes bajo cualquier rótulo descalificatorio: Nietzsche, el loco sifilítico ávido de salud, el ateo nostálgico de Dios, el inmoralista precursor de la ralea nazi... Así se tranquiliza nuestra buena conciencia ante el temor de no haber entendido nada. «¿Se me ha entendido? Lo que me separa del resto de la humanidad es el haber descubierto la moral cristiana». ¿Cómo? ¿La moral cristiana? ¿Acaso un malentendido? ¿Y si lo que hemos tomado como criterio máximo de valor no fuera sino una interpretación resentida de la existencia, que la deprecia al juzgarla por el rasero de un inexistente más allá ideal — sin el cual, se dice, este mundo carecería por completo de sentido- convirtiendo en pecado los presupuestos mismos de la vida (la fuerza, la salud, el placer) y celebrando su renuncia? Tal es la inquietante sospecha sembrada por Nietzsche, sospecha que desborda los contenidos de un determinado credo religioso e involucra a todo cuanto constituye el estilo dominante del pensar occidental, a eso que él califica, en modo necesariamente simplificador, de "platónico»: una actitud de rechazo insuperable ante la tragicidad de la vida, una ascética manía de trasmundos, promotora de una lectura decadente de los grandes relatos de nuestra cultura, incluido el mensaje cristiano, convertido así en un platonismo plebeyo, cuando su significado pudo haber sido otro bien distinto: «El reino de los cielos es un estado del corazón, no algo situado por encima de la tierra o que llegue tras la muerte [...] En el fondo, sólo hubo un cristiano, y murió en la cruz» (KSA VI 211).

Antes que un crítico de la religión cristiana, Nietzsche es, por tanto, un crítico de la metafísica "platónica» que ha seguido estando a la base de los aspectos menos saludables de nuestra civilización, y es desde la conjugación de estas coordenadas desde donde tiene sentido revisar hoy, a más de un siglo de distancia, su legado. Éste es el motivo por el que siguen siendo tan frecuentes las apelaciones a la exégesis de Heidegger en el ámbito de la Nietzsche-Forschung: no por una presunta connivencia con cierto eje del mal posmoderno, del que ambos pensadores formarían su más conspicua representación, ni por una fiel adhesión a los presupuestos de la lectura heideggeriana de Nietzsche como último avatar del nihilismo, sino porque Heidegger supo llevar a primer plano la importancia de Nietzsche como pensador del final de la metafísica y acertó a desarrollar a partir de ahí una estimulante confrontación con su obra, que devolvió a los grandes temas de la filosofía nietzscheana - muerte de Dios, superhombre, voluntad de poder, eterno retorno- una gravedad que amenazaba con perderse entre tantas interpretaciones peregrinas como de ellos circulaban por aquel entonces. Lo cual

2. KSA VI 365 (Ecce homo, trad. de A. Sánchez Pascual, Madrid: Alianza, 1971, p. 123). 
no quita obviamente para expresar ahora, en nuestro propio contexto históricohermenéutico, tras los logros de un trabajo filológicamente más concienzudo con los manuscritos, la necesaria reserva hacia sus muchas lecturas descontextualizadas, así como las oportunas discrepancias con la manera en que Heidegger hubo de desdibujar los perfiles más significativos del Nietzsche crítico de la cultura, a fin de ganar su límpida imagen de pensador de la historia del ser.

De todo esto vamos a tratar en lo que sigue, y lo vamos a hacer en relación con el problema del «radicalismo aristocrático» ${ }^{3}$ de Nietzsche, tal como éste se refleja en sus consideraciones sobre arte, política y cultura de la décadence. Se ha hablado bastante en los últimos años de «estetización de la política», para referirse a las claves del sesgo conservador del pensamiento político de Nietzsche ${ }^{4}$. En dos sentidos, al menos, me parece inadecuado este modo de plantear la cuestión del «déficit democrático» de la filosofía nietzscheana. En primer lugar, sugiere la equívoca idea de que es la intrusión de una perspectiva procedente del estricto terreno del arte en el campo específico de la política lo que ha fomentado en Nietzsche una visión completamente alejada de los verdaderos problemas y las variables reales que operan en todo análisis riguroso del entramado social. En el mejor de los casos, se disculpa la ingenua actitud del teórico ajeno a las cuestiones mundanas, que ha sublimado un mundo trágico-heroico sin contar con las consecuencias negativas de su diletante propuesta. En el peor, se denuncia el cínico realismo de quien no ha reparado en la posibilidad de ingentes sacrificios humanos con tal de que la gran política consiga dar a la luz una especie de hombre superior, capaz de realizar una cultura artística a su medida. En ambos casos, es la imagen idealizada del artista que modela un mundo a su antojo — réplica y proyección hiperbólica a un tiempo del paradigma wagneriano- lo que parece haber contaminado el pensamiento político de Nietzsche, hasta convertirlo en terreno abonado para que en él hayan podido germinar algunas de las más terribles ideologías autoritarias del siglo $\mathrm{xx}^{5}$.

Resulta bastante discutible, sin embargo, que esta figuración ultrarromántica del papel del artista en la sociedad, inducida entre otros motivos por su juvenil deslumbramiento ante la personalidad de Wagner, sea la imagen última

3. La expresión se remonta al trabajo pionero de Georg Brandes «Aristokratischer Radicalismus. Eine Abhandlung über Friedrich Nietzsche», publicado originalmente en Deustche Rundschau, vol. LXIII (1890), 67-81. Hay un extracto de este ensayo en el volumen colectivo editado por Alfonso Moraleja, Nietzsche y la "gran política». Antídotos y venenos del pensamiento nietzscheano, Madrid: Cuaderno Gris/UAM, 2001, pp. 27-40.

4. Cf., en especial, B. Detwiler, Nietzsche and the Politics of Aristocratic Radicalism, Chicago: University of Chicago Press, 1990 y J. Quesada, «Estetización de la política en Nietzsche», en Id., La belleza y los humillados, Barcelona: Ariel, 2001, pp. 37-64. En el volumen colectivo citado en la nota anterior, puede verse asimismo la introducción de Alfonso Moraleja, pp. 9-24 (de «esteticismo apolítico amoral o inmoral» se califica la postura de Nietzsche en la p. 11).

5. Ésta es, sin matices, la posición que expresa Ernst Nolte, y, más que en su controvertido Nietzsche und der Nietzscheanismus (Frankfurt/Berlin: Propyläen, 1990), ya anteriormente en El fascismo en su época (Madrid: Península, 1967): «Nietzsche no es el padre del fascismo en un sentido banal. Es el primero en expresar de un modo amplio aquel centro espiritual hacia el cual gravitan todos los fascismos: el ataque a la trascendencia práctica y teórica, pero con la voluntad de crear una configuración 'bella' de la vida». A esta línea de lectura, que tiende a reducir la óptica nietzscheana a una contraposición romántica entre Bildung y política, se adhiere expresamente el trabajo citado supra de Alfonso Moraleja. 
de Nietzsche al respecto. Por otra parte, no deja de latir en semejante reproche, que vuelve a reiterar el gesto de destierro del poeta por su frívola mirada sobre los serios asuntos de la ciudad, cierto prejuicio platónico, que también merecería ser examinado como síntoma de aquella vieja fe metafísica en la existencia de un fundamento racional, universal e incontrovertible, del cual deducir sin distorsión los principios de la convivencia ${ }^{6}$. Nietzsche, evidentemente, no comparte el optimismo de esa fe racionalista, y por ello insiste en el carácter artificioso de todo contrato social, en el soterrado conflicto de fuerzas, intereses y pasiones sobre el cual se alza todo sistema de derechos o en la banal confianza de la doctrina económica liberal en una autorregulación de los mercados y una tendencia final al equilibrio y a la distribución igualitaria de la riqueza. Pero al hallar todas estas incómodas consideraciones en sus textos, no deberíamos precipitarnos en fustigar al mensajero y condenarlo por lo desalentador que suena su mensaje a nuestros oídos. Esta actitud es, empero, bastante frecuente entre quienes denuncian una estetización de la política en Nietzsche, y constituye el segundo motivo por el que este tipo de planteamiento me parece insatisfactorio: insiste en achacar al pensamiento nietzscheano un menosprecio de la política que tendría su razón de ser en la adopción de un punto de vista metapolítico, esteticista y amoral, donde la argumentación racional se vería sustituida por la pura y simple imposición de la fuerza, una vez que se ha asumido la tesis nihilista de que no hay sentido ni criterio alguno de valor. Dicho planteamiento reduce en el fondo toda la complejidad del decurso intelectual de Nietzsche a un enquistamiento en la lectura más rabiosamente antiilustrada de su temprana afirmación de que «sólo como fenómeno estético están eternamente justificados la existencia y el mundo» ${ }^{7}$. Según este parecer, la óptica del arte aplicada por Nietzsche a su tratamiento del discurso filosófico lo habría sumido en un caótico relativismo, para salir del cual no habría alcanzado a vislumbrar otra vía que la de la apelación a la figura carismática del genio y, en suma, a la restauración de un principio fuerte de autoridad. Algo sumamente discutible para quienes, por el contrario, han sabido hallar en la crítica nietzscheana a la concepción sustancialista de la identidad un estímulo más para abogar por el pluralismo de los valores. Y ello sin necesidad de limitarse al ámbito de una comprensión de la vida como literatura, en donde intérpretes como Alexander Nehamas han defendido también las diferencias existentes entre el perspectivismo nietzscheano y el puro relativismo ${ }^{8}$. Pues lo que se deriva propiamente de la muerte de Dios es la imposibilidad de reducir todas las perspectivas a una sola, tomada como la única válida y verdadera, generando así un clima de necesario conflicto y productiva interferencia entre los diferentes puntos de vista, que es lo que caracteriza a las formas democráticas modernas de organización de la vida social. Lejos de conculcar estas formas, hay aspectos del pensamiento nietzscheano que resultan aprovechados en la actualidad por autores como Alan D. Schrift,

6. Éste es el caso destacado del trabajo de Luc Ferry y Alain Renaut, «Ce qui a besoin d'être demontré ne vaut pas grand-chose», incluido en el volumen colectivo editado por ambos autores, Pourquoi nous ne sommes pas nietzschéens, Paris: Grasset \& Fasquelle, 1991, pp. 129-152. Hay trad. cast. en A. Moraleja (ed.), Nietzsche y la "gran política», cit., pp. 169-182.

7. KSA I 47.

8. A. Nehamas, Nietzsche: Life as Literature, Harvard: Harvard University Press, 1985. 
Bonnie Hönig o Chantal Mouffe para profundizar en un concepto más radical de democracia, apostando por el agonismo de los valores democráticos como fuente constante de pluralismo político frente a una visión todavía demasiado esencialista del consenso normativo?.

Aun así, no es ésa la línea de argumentación que me interesa desarrollar aquí. Sería fácil, por lo demás, entresacar textos de Nietzsche en los que éste se expresa en un sentido muy distinto al que le reprochan sus detractores ${ }^{10}$. Estas operaciones exegéticas, de las que está plagada la literatura secundaria en torno al solitario de Sils-Maria, practican a menudo con sus escritos mayor violencia hermenéutica que la que le atribuyen a su concepción del mundo como una obra de arte que incesantemente se hace a sí misma. Seleccionan una serie de pasajes, los separan de su contexto y les imponen desde fuera una determinada orientación; o bien, en el extremo contrario, deciden una plena sistematización del corpus nietzscheano a partir de aquello que les resulta más significativo, encerrándolo bajo una unidad arbitraria. Tanto uno como otro proceder aspiran a presentar su obra como un todo concluso. Heidegger ha incurrido con frecuencia en esa clase de lectura totalizadora, en su afán de caracterizar la posición de Nietzsche dentro de la historia de la metafísica como la de un nihilismo terminal, sólo contestado de veras por su propio pensar rememorante. Quienes se afanan ahora en avisarnos de la peligrosidad política de Nietzsche, tienden asimismo a reducir su crítica de la razón a una metafísica irracionalista y su crítica de la cultura a un programa político de signo reaccionario. Es todo un síntoma el que, en medio de esta atmósfera plagada de corrección política, la simple apelación nietzscheana al arte como movimiento opuesto al nihilismo reactivo despierte las mayores suspicacias. Sin embargo, ha sido justamente la imbricación entre poesía y verdad, entre trabajo del mito y trabajo del logos, lo que ha permitido al singularísimo estilo del pensamiento de Nietzsche no quedar atrapado sin más en las redes del lenguaje de la metafísica precedente y conceder a la filosofía un nuevo modo de entender su discurso y de ejercer la crítica, recogiendo el testigo del espíritu antidogmático de la Ilustración. Un modo que cuestiona de entrada la pretensión de cerrar la interpretación en un punto definitivo. Tan consciente es Nietzsche de que su escritura filosófica se configura como un acto interpretativo sobre el tapiz interminable de la existencia, que una y otra vez cede al vértigo de explorar y expresar las diferentes posibilidades que se abren en un mundo desprovisto de centro, arrojado a una errancia sin fin. Naturalmente, esto no significa que el estudioso de su obra no deba arriesgar una interpretación, o que haya de contentarse con proclamar un indiferentismo hermenéutico, según el cual todas las lecturas son igualmente válidas e intercambiables. Pero sí insta a

9. A. D. Schrift (ed.), Why Nietzsche Still? Reflections on Drama, Culture and Politics, Berkeley: University of California Press, 2000, pp. 184-201; B. Honig, «The Politics of Agonism»: Political Theory 21/3 (1993), 528-533; C. Mouffe, The Return of the Political, London: Verso, 1993.

10. Como muestra exagerada y sacada de contexto, valga este subversivo botón, perteneciente a un fragmento póstumo del año 1875: «iAbajo el arte que no impulse la revolución social, la renovación y la unificación del pueblo!» (KSA VIII 218: 11[28]). De forma más rigurosa cabe documentar, en cambio, desde los escritos del período intermedio, su rechazo del odio racial preconizado por la ideología pangermanista, así en este fragmento póstumo de primavera-otoño de 1881: «Quien odia o desprecia la sangre extranjera, aún no es un individuo, sino una especie de protoplasma humano» (KSA IX 555: 11[296]). 
preservar el carácter dinámico, paradójico y tantas veces contradictorio del pensamiento nietzscheano, a fin de alcanzar una comprensión más amplia del intrincado proceso de elaboración de sus ideas. Interrumpir este proceso, condensarlo en una serie de tesis, sólo sirve al insulso cometido de pontificar si a estas alturas debemos o no proclamarnos nietzscheanos, pero poco contribuye a aclarar qué nos sigue aportando este intempestivo filósofo, pese a tantos ademanes grandilocuentes y énfasis guerreros que ya no compartimos con él, a la hora de repensar nuestras verdades. Éste es, insisto, el reparo que me parece lícito hacer a la mayoría de las condenas del llamado «esteticismo político» nietzscheano. No que discutan sus proclamas a favor de una nueva casta dominante o que deploren, en general, la faceta más sombría y autoritaria de sus ideas sobre la gran política -objeciones con las que, grosso modo, puede estar uno de acuerdo-, sino que reduzcan por ello todo el conjunto de su pensamiento a un "antimodernismo radical» ${ }^{11}$, que, en su apelación al arte como principal poder de fabulación de mundo, estaría delatando el más profundo irracionalismo. Con ello se bloquea cualquier posibilidad de apreciar aspectos positivos en la crítica nietzscheana de la Modernidad, bien necesarios hoy para desenmascarar los falsos ídolos de nuestra normalidad democrática, del igualitarismo ramplón, que suprime toda idea de excelencia y valoración del esfuerzo, a la obtusa inmersión -ésa, sí, verdaderamente apolítica - en la vulgaridad, supuestamente glamurosa, de la actual cultura de masas; al igual que se obvian las ambigüedades y tensiones de su discurso, cuando, de hecho, son éstas las que mejor nos ponen sobre la pista del modo en que Nietzsche supo ahondar en su temprano diagnóstico sobre la decadencia, hasta desprenderse de muchos de los elementos típicos de la crítica cultural conservadora de orientación romántica, que en buena medida asumió en sus primeros escritos. Para valorar esta dimensión de la filosofía de Nietzsche, no es preciso minimizar la importancia de sus duras expresiones en pro de una sociedad fuertemente jerarquizada. Considero, en cambio, que es perfectamente posible compaginar ambos aspectos dentro de una lectura más matizada, que sepa distanciarse tanto de las simplezas de la asimilación de Nietzsche al nazismo cuanto de la sofisticación hiperlibertaria y, en el fondo, neorromántica de algunos de sus lectores posmodernos.

Quiero argumentar, por consiguiente, que no es la concepción nietzscheana del arte como modelo de un nuevo régimen de relación con la verdad lo que estropea y pervierte su pensamiento político. En particular, resulta sumamente erróneo atribuir al Nietzsche maduro el regreso a una metafísica de artista, donde el arte volvería a quedar consagrado como lugar de manifestación de la verdad del ser y su proyecto de renovación cultural quedaría definitivamente orientado hacia un romanticismo reaccionario, con todos los tics que muestra el rechazo de la Zivilisation moderna por parte de muchos intelectuales alemanes de la época y de los círculos wagnerianos en particular: nacionalismo, belicismo, antisemitismo, pangermanismo... Muy brevemente, hay que recordar que Nietzsche se ha pronunciado expresamente contra todos y cada uno de estos rasgos, a su juicio deleznables, que se concentran finalmente en la política imperialista de la Alemania de Bismarck y la dinastía Hohenzollern ${ }^{12}$. Yendo a lo fundamental,

11. L. Ferry y A. Renaut, op. cit., p. 175.

12. El parágrafo 377 de La gaya ciencia, titulado «Nosotros, los apátridas», es un claro ejemplo 
hay que decir que, por el contrario, es precisamente la meditación nietzscheana sobre la función del arte una vez que el mundo verdadero ha acabado convirtiéndose en fábula la que ha madurado con mayor prontitud e intensidad a partir del desengaño del ideal wagneriano y la que le ha permitido emanciparse del modo más resuelto de las hipotecas románticas de su primera filosofía.

Nietzsche no toma el arte, pues, como actividad de una esfera específica que se extiende de manera abusiva a todo el espectro de la acción humana, sino como ejemplificación de un tipo de trato con la realidad que no esconde la dosis de invención, recreación y adaptación a determinada configuración vital que se da en el curso de su intento de expresar dicha realidad. Esto no implica el abandono nihilista de toda posibilidad de verdad y la huida esteticista hacia cínicos paraísos artificiales. De hecho, se trata de una consecuencia extraída en primera instancia por la filosofía y la ciencia modernas a partir de la crítica de la metafísica y del reconocimiento del carácter fenoménico de nuestro conocimiento. Es la orientación de su pensamiento que va a desarrollarse fundamentalmente a partir del ensayo de 1873, Sobre verdad y mentira en sentido extramoral, y que conduce al "período ilustrado». Una vez cuestionada seriamente la posibilidad de acceso a un fundamento indubitable de lo real, nuestras verdades quedan necesariamente relativizadas, mas no por ello anuladas o desechadas. No se trata de una sustitución de la verdad por la apariencia, sino de un aprendizaje de los términos de su íntima trabazón. El constante trabajo de poetización y metaforización del mundo no puede prescindir del punto de vista crítico y desencantado que ha aportado el desenvolvimiento de la razón, si no quiere volver a confundir sus tentativas de desciframiento de lo real con un discurso metafísico directamente enlazado a la «cosa en sí». La tarea de reconstrucción del proceso a través del cual el hombre ha ido contribuyendo a la constitución del sentido de las cosas, olvidando luego dicho proceso y atribuyéndole un origen "puro», esto es, absolutamente ajeno a él, no puede quedarse en una conclusión meramente negativa, en «una negación lógica del mundo» ${ }^{13}$, sino que ha de acostumbrarse a considerar en qué medida el error sobre la vida es necesario para la vida. Para ello es para lo que el arte se

de la irreductibilidad del pensamiento político nietzscheano a esos esquemas duales preconcebidos. Nietzsche ataca ahí tanto el inmovilismo reaccionario del culto a los viejos valores cuanto la tendencia niveladora del progresismo escatológico, cuya promesa de un orden más justo y armónico le parece una mera excusa para propagar «el reino de la más profunda mediocridad y de las banalidades»: «No, nosotros no amamos a la humanidad; por otra parte, no somos, ni con mucho, lo bastante 'alemanes', tomada la palabra 'alemán' en el sentido corriente que hoy tiene, para preconizar el nacionalismo y el odio racial [...]. Somos demasiado libres de prejuicios, maliciosos y refinados, estamos también demasiado bien informados, 'viajados', para eso: decididamente, preferimos vivir en las montañas, aparte, inactuales, en siglos pasados o venideros, con tal de ahorrarnos la rabia callada a que nos sabríamos condenados como testigos oculares de una política que, al volver vanidoso al espíritu alemán, lo vuelve estéril y es una política mezquina, por añadidura — ¿no se ve ella obligada a plantar su propia creación entre dos odios mortales, para que no se deshaga al momento?, ¿no tiene que desear que se eternice la Europa de los pequeños Estados?... Nosotros, apátridas, somos demasiado múltiples y mezclados en cuanto a raza y origen, en cuanto 'hombres modernos', y en consecuencia poco dispuestos a participar de la mendaz autoadmiración y del impudoroso racismo que se exhibe hoy día en Alemania como signo de fe alemana y que aparece en el pueblo del 'sentido histórico' doblemente falsa e indecente» (KSA III 630-631; La gaya ciencia, trad. de C. Crego y G. Groot, Madrid: Akal, 1988 [=GC], pp. 306-307).

13. KSA II 52 (Humano, demasiado humano, trad. de A. Brotons, Madrid: Akal, 1996, vol. I, [= HH I], p. 60). 
muestra como un mentor de excepción, porque en él se ha seguido ejercitando sin mala conciencia el poder de conjunción de realidad y ficción. Así es como llega Nietzsche a esa conclusión que tantas veces se expresa en su obra de madurez con un extremismo deliberadamente provocativo:

Que la verdad sea más valiosa que la apariencia, eso no es más que un prejuicio moral; es incluso la hipótesis peor demostrada que hay en el mundo. Confesémonos al menos una cosa: que no existiría vida alguna a no ser sobre la base de apariencias y apreciaciones perspectivistas; y si alguien, movido por la virtuosa exaltación y majadería de más de un filósofo, quisiera eliminar del todo el «mundo aparente», entonces, suponiendo que vosotros pudierais hacerlo, - itampoco quedaría ya nada de vuestra «verdad»! Sí, ¿̇ué es lo que nos fuerza a suponer que existe una antítesis esencial entre "verdadero» y «falso»? ¿No basta con suponer grados de apariencia y, por así decirlo, sombras y tonos generales, más claros y más oscuros, de la apariencia - valeurs diferentes, para decirlo en el lenguaje de los pintores? ${ }^{14}$.

El arte aparece entonces, según leemos en el último aforismo del libro segundo de La gaya ciencia, como la «buena voluntad de la apariencia», es decir, como esa modalidad de culto a la no verdad que ahora nos permite acostumbrarnos a las nuevas exigencias de la visión del mundo proporcionada por la ciencia: «la visión de la ilusión y del error como condición de la existencia cognoscente y sensible» ${ }^{15}$, como añade ahí Nietzsche. Pero obsérvese que no se trata de una exigencia arbitrariamente impuesta por el tirano-artista o el genio-filósofo, sino derivada del quehacer crítico de una razón que a lo largo de la Modernidad ha ido autonomizándose cada vez más respecto de instancias transcendentes de donación de sentido último, hasta ejercer dicha crítica sobre sí misma. Esto hace que los planteamientos filosóficos del Nietzsche maduro se distingan netamente de los formulados en El nacimiento de la tragedia, donde, aunque de manera cargada de ambigüedades ${ }^{16}$, el arte se presentaba todavía como medio privilegiado de acceso a una verdad superior y por completo distinta al conocimiento del mundo aparente, representacional, suministrado por la ciencia. Todo ello cambia con el viraje genealógico que comienza a cuajar a partir de Humano, demasiado humano. Si el último Nietzsche vuelve a manifestar su predilección por el arte, ya no es por estimar que se trata de un lenguaje que nos pone en contacto directo con una realidad que transciende las formas fenoménicas, sino porque considera que, dentro de la cultura occidental, éste ha sido el ámbito de expresión donde mejor se ha conservado el espíritu trágico-dionisíaco, entendiendo ahora por tal aquel que asume sin nostalgia la quiebra del fundamento metafísico y celebra la apariencia como lo actuante y viviente mismo, tras de lo cual no es preciso suponer una esencia ni una desconocida $x$ (KSA III 417). No se trata ya, así pues, de apreciar el arte porque allí se haya depositado una verdad

14. KSA V 53-54 (Más allá del bien y del mal, trad. de A. Sánchez Pascual, Madrid: Alianza, 1983, p. 60).

15. KSA III 464 (GC 145).

16. He tratado algunas de estas ambigüedades en mi libro Voluntad de lo trágico. El concepto nietzscheano de voluntad a partir de «El nacimiento de la tragedia», Madrid: Biblioteca Nueva, 2002. 
originaria, sino porque a través de su influencia comienza a hacerse problemático el establecimiento de un hiato ontológico entre dos ámbitos de realidad, a los cuales correspondería la distinción fuerte entre un discurso de la doxa y otro de la epistēme. Para Nietzsche, éstas son distinciones inmanentes, de naturaleza estrictamente histórica, fruto del progresivo establecimiento de diferentes esferas de actuación en el ejercicio del logos a partir del primitivo impulso del hombre a la formación de metáforas. Y a toda esta serie de conclusiones sobre el carácter devenido de nuestras representaciones morales, estéticas, metafísicas y religiosas llega Nietzsche mediante una indagación genealógica, que expresamente se reclama deudora de los métodos de la ciencia contemporánea ${ }^{17}$.

Que, por lo tanto, afirmaciones de Nietzsche relativas al carácter de su indagación, como la de que «el ideal no es refutado - se congela» (KSA VI 323), constituyan una demostración fehaciente de su pleno rechazo de la argumentación racional y, consiguientemente, de su apelación a la fuerza y a la imposición violenta como único modo de establecer criterios y valores, es una de las muchas simplificaciones y torcidas interpretaciones en las que incurren autores como Luc Ferry y Alain Renaut cuando se dedican a explicarnos por qué no son nietzscheanos $^{18}$. En realidad, la «congelación» del ideal supone estrictamente un procedimiento de investigación basado en lo que el Nietzsche del período intermedio denomina «filosofar histórico»: un primer nombre para lo que luego se ha de llamar «genealogía» y que, si no necesita refutar el ideal para desenmascararlo, es porque no requiere oponerle la tesis contraria, negándole por completo sentido y validez; le basta con mostrar, precisamente a través de la reconstrucción histórico-crítica del proceso de su génesis, cómo una cosa puede proceder de su contraria. La explicación de la procedencia de los valores superiores desmonta por sí sola su pretensión de arrogarse un «origen milagroso», como si derivasen «inmediatamente a partir del núcleo y la esencia de la 'cosa en sî’» (KSA II 23). $\mathrm{Al}$ no quedar cuestionado desde una verdad más originaria, en el sentido de más real o más próxima a ese presunto núcleo esencial, el ideal no resulta propiamente refutado, esto es, desechado y sustituido por otro, que ahora vendría a afirmarse como más auténtico. Simplemente, se comprende como resultado de un proceso histórico, ya que «todo ha devenido; no hay datos eternos, lo mismo que no hay verdades absolutas» (KSA II 25). Pasa a formar parte, así pues, de las pequeñas verdades inaparentes que trenzan nuestra existencia. Tomar esta «modestia» (ibid.) de la crítica nietzscheana por un signo de irracionalismo no sólo supone desconocer el contexto histórico-filosófico y científico en que se genera tal concepción, sino negarse a admitir que dicho contexto responde a una profundización del impulso más distintivo de la Modernidad filosófica, su confrontación con el dogmatismo metafísico. En congruencia con este talante, Nietzsche arguye que lo propio de una cultura que ha llegado a descubrir que verdades

17. Cf. el aforismo primero de HH, "Química de las ideas y los sentimientos morales», KSA II 23-24.

18. L. Ferry y A. Renaut, op. cit., pp. 172-173. Frente a esta lectura, véase por ejemplo lo que dice Nietzsche en el «Ensayo de autocrítica» redactado en 1886 como prólogo a la tercera edición de El nacimiento de la tragedia, en el que lamenta la falta de «voluntad de limpieza lógica» de su primer libro, un «libro para iniciados», «muy convencido, y que por ello se exime de dar demostraciones, desconfiando incluso de la pertinencia de dar demostraciones» (KSA I 14; El nacimiento de la tragedia, trad. de A. Sánchez Pascual, Madrid: Alianza, 1997 [= NT], p. 28). 
superiores y pequeñas verdades no proceden sino de un mismo suelo de finitud y contingencia, es reclamar «igualdad de derechos» (ibid.) para ellas en cuanto a su estatuto epistemológico. Aquí, el gesto inquisitivo del genealogista no es en absoluto de desprecio, sino de humilde aceptación de la fragilidad de los bienes que heredamos del pasado de la humanidad y que ahora llegamos a estimar cabalmente "como un tesoro» ${ }^{19}$. Nietzsche advierte que esta situación genera inseguridad y escepticismo, pero no trata de remontar esta incerteza por medio de un salto irracional, a lo Jacobi, hacia la intuición estética de un absoluto. Toda su meditación última sobre el papel del arte en el mundo contemporáneo mantiene como presupuesto esta consecuencia irrenunciable que se deriva de la conciencia moderna de la muerte de Dios. La conversión del mundo verdadero en fábula no conduce a una subordinación o a una subsunción de la filosofía en la literatura. Es el propio trabajo crítico del concepto sobre sí mismo el que descubre que a su base hay una actividad «artística». Difícilmente puede hablarse, por tanto, de puro esteticismo en este punto crucial de maduración de la mirada genealógica nietzscheana, cuando su detonante más claro es, sin duda, el abandono de la solución estética al problema de la cultura moderna propuesta en El nacimiento de la tragedia, al amparo de Schopenhauer y Wagner. Veámoslo con más detalle.

«Ya en el verano de 1876, a mediados de temporada de los primeros Festivales de Bayreuth, tuvo lugar dentro de mí una despedida de Wagner. No soporto nada equívoco: desde que Wagner estuvo en Alemania, condescendió paso a paso con todo lo que yo desprecio - incluso con el antisemitismo... Fue entonces, en efecto, el momento cumbre para la despedida: pronto obtuve una prueba de ello. Richard Wagner, en apariencia el máximo triunfador, en realidad un podrido y desesperado décadent, se postró de improviso, desesperado y abatido, ante la cruz cristiana. [...] Cuando proseguí en solitario mi camino, temblaba; no mucho después, caí enfermo, más que enfermo, cansado, [...] cansado de la náusea ante toda la mentira idealista» ${ }^{20}$.

La polémica con el esteticismo wagneriano es, en efecto, lo que precipita en Nietzsche el ahondamiento en su labor de crítica de la metafísica tradicional. Constituye, por tanto, un proceso de evolución y emancipación intelectual del que podrían rastrearse indicios hasta en el propio texto de El nacimiento de la tragedia, en la medida en que ya el joven Nietzsche ha mantenido discrepancias de fondo con la concepción wagneriana del drama musical; pero dicho proceso comienza a mostrar señales inequívocas sobre todo a partir del período de 1875 1876, durante el cual Nietzsche redacta su cuarta Consideración intempestiva,

19. KSA II 37 (HH I 52). Me permito remitir asimismo a un comentario más detallado de este pasaje en mi estudio introductorio a esta edición, "Nietzsche: la crítica de la metafísica como curvatura de la Ilustración", pp. 7-27.

20. KSA VI 431-432 («Nietzsche contra Wagner» [=NW], trad. de M. Barrios Casares: Er, revista de filosofía 14 [1992], El más inquietante de todos los huéspedes, número monográfico dedicado a Friedrich Nietzsche, p. 202). 
Richard Wagner en Bayreuth ${ }^{21}$. Es una etapa que coincide de forma significativa con un sensible empeoramiento de la salud del filósofo, hasta el punto de tener que abandonar definitivamente en 1879 la cátedra de filología clásica de la Universidad de Basilea e iniciar su existencia itinerante, en busca de lugares y climas capaces de aliviar los síntomas de su enfermedad. Resulta de lo más ilustrativo, en ese sentido, correlacionar la manera en que Nietzsche ha ido afinando y precisando una comprensión del proceso de su enfermedad y el modo en que ha ido revisando su primer diagnóstico sobre la decadencia cultural del presente. En la correspondencia de esos años, conforme más se agudizan los dolores de cabeza y más penoso se hace el trabajo, Nietzsche ensaya diferentes respuestas a la pregunta por el origen de sus padecimientos ${ }^{22}$. En ocasiones lo atribuye al esfuerzo agotador de su rutinaria existencia libresca. Otras, en cambio, a la pérdida de ese ritmo ordenado de estudio y meditación, debido a la disipación que le supuso su ingreso en el círculo de Wagner. Más que los días pasados en «la isla de los bienaventurados» de Tribschen, lo que Nietzsche deplora en este caso es la atmósfera fingidamente revolucionaria, en realidad profundamente burguesa de Bayreuth; y lo que entre forzados intentos de alabar al maestro y salvarlo de los wagnerianos emerge ya con nitidez en la cuarta Intempestiva es la catalogación de Wagner como comediante de sí mismo. Mas ¿̇cuál es el verdadero motivo por el que hubo de enfermar el señor Nietzsche? ¿Las exigencias de un trabajo abrumador y sin auténtica conexión con los problemas vitales, como él mismo le achaca a la filología académica de su tiempo? ¿O las morbosas veleidades místicas del universo impostado por el artista romántico? En el prefacio de 1886 a la segunda edición de La gaya ciencia (1882), glosando su convicción de que ese escrito documenta la experiencia de una profunda cura tras haber padecido la enfermedad del ideal, comenta Nietzsche:

El psicólogo conoce pocas cuestiones tan fascinantes como la de la relación existente entre la salud y la filosofía y, en caso de caer enfermo él mismo, aporta a su enfermedad toda su curiosidad científica. Pues, si uno es una persona, necesariamente tiene también la filosofía de su persona: hay en esto, empero, una gran diferencia. En algunos, lo que filosofa son sus defectos, en otros, sus riquezas y fuerzas. Aquéllos necesitan su filosofía, como su sostén, calmante, medicina, redención, edificación, enajenación de sí mismos; para éstos la filosofía es tan sólo un hermoso lujo, en el mejor de los casos la voluptuosidad de una gratitud triunfante que finalmente debe inscribirse con mayúsculas cósmicas en el firmamento de los conceptos ${ }^{23}$.

No es aventurado suponer que Nietzsche no está pensando aquí tan sólo en su caso, sino también en «el caso Wagner», en lo que implica el contraste entre una creación — artística, filosófica - nacida de la capacidad de afrontar

21. Sobre estos distintos pasajes de la ruptura con Wagner, véanse los esclarecedores trabajos de D. Sánchez Meca, «El adversario interior»: Estudios Nietzsche 1 (2001), 119-144, y L. E. de Santiago Guervós, «F. Nietzsche y la quiebra del ideal artístico wagneriano», en J. B. Llinares, Nietzsche. 100 años después, Valencia: Pre-Textos, 2002, pp. 113-133.

22. Cf. G. Campioni, «'Todo enfermo es un canalla...' Enfermedad y espíritu libre en las cartas de Nietzsche de 1875 a 1879»: Estudios Nietzsche 1 (2001), 33-47.

23. KSA III 347 (GC 30-31). 
el dolor de la existencia o urgida por la necesidad de calmarlo. Y que el hecho de pensar las interferencias entre estas dos actitudes le lleva a complicar tanto las claves de su diagnóstico de la decadencia cuanto los modos de proponer un restablecimiento, una vez se da cuenta de que él mismo ha caído enfermo. Ciertamente, el Nietzsche nostálgico de una gran salud inmaculada nos asalta a veces con voz tronante, proponiendo una dureza sobrehumana y un despiadado desprecio de todo lo enfermizo, debilitado, parasitario que hay en la existencia. Sus objeciones fisiológicas al arte romántico, que trata de ocultar el elemento trágico o redimirlo a través del ingreso en un nirvana cualquiera, adoptan entonces como complemento el tono belicoso de la «fe en una virilización de Europa». Su repudio de la mixtificación wagneriana, simuladora de una intensa renovación de todo el horizonte vital y cultural de su tiempo, pero dedicada de hecho a halagar el gusto de la masa, le lleva a replicar con una contundencia que a menudo resulta equívoca incluso para él mismo. Es curioso que los detractores del Nietzsche autoritario suelan adjudicarle a renglón seguido el marchamo de pensador esteticista, porque los términos en que vino a explicitarse la polémica entre Wagner y el filósofo fueron justamente los contrarios. Al creciente desacuerdo de Nietzsche con la total teatralización de la existencia pretendida por Wagner - desacuerdo que se concreta en Humano, demasiado humano mediante una relegación del arte a cosa del pasado- contestaría Wagner en Público $y$ popularidad acusando a Nietzsche, sin mencionarlo, de «filisteísmo cultural» y falta de instinto artístico para reconocer al genio, así como de sometimiento racionalista («ilustrado») «a los resultados del nuevo método científico, llamado 'histórico'» ${ }^{24}$. Llama la atención que Wagner haya empleado ahí contra Nietzsche conceptos y argumentos tomados de la crítica al docto expuesta en El nacimiento de la tragedia y en las Consideraciones intempestivas. Resulta evidente que Nietzsche ha mudado de piel. Pero se equivoca Wagner al querer apresar su nueva orientación de pensamiento bajo un registro del pasado, sea en clave positivista o historicista, tal como se equivocan quienes se contentan con asimilarlo sin más al difuso horizonte del idealismo romántico. Los pares instinto-razón, salud-enfermedad, cruzados de un modo u otro, siguen siendo insuficientes para captar la dinámica de este pensar si se insiste en tomarlos por separado y como antagonistas absolutos. El propio Nietzsche ha dudado y oscilado en este sentido, como cuando trataba de determinar las causas de su caída en la enfermedad del ideal. Al final, recuerda oportunamente Giuliano Campioni,

en Ecce homo, ya no hay contradicción entre las dos vías: una se remite necesariamente a la otra. La mecanicidad y miseria de la «profesión» necesitan como narcótico, para «anestesiar un sentimiento de hambre y desolación», un arte que idealice, transfigure y aleje de la realidad ${ }^{25}$.

Tal es, en efecto, el tipo de análisis más depurado y matizado que hallamos ya en el aforismo de El caminante y su sombra titulado «El arte en la época del

24. Crítica histórica, añade Wagner, «que está sumergida en el judaísmo» y procede asimismo de la Ilustración (Publikum und Popularität, en Gesammelte Schriften und Dichtungen, Leipzig, 1907 ss., vol. X, pp. 84-86).

25. G. Campioni, loc. cit., p. 47. 
trabajo»: pese a la apariencia contraria, el arte romántico no pone en cuestión la creciente rutinización e instrumentalización de la vida diaria en una sociedad cuyo objetivo fundamental es la explotación económica y la maximización de beneficios. Se limita a funcionar como anestésico en los momentos de dolor o como excitante artificioso de fuerzas gastadas en los éxtasis puntuales al final de la jornada laboral, proporcionando efímeras dosis de evasión antes del retorno a la cruda realidad ${ }^{26}$. Nietzsche, implacable en su disección de las falacias de la vida moderna, no sólo desenmascara este ineficaz populismo en el caso del arte wagneriano, sino también en relación con el halago demagógico de las masas que se extiende cada vez más por todo el espectro político ${ }^{27}$.

Ahora bien: aunque puede que la decadencia que Nietzsche denuncia en Wagner comience adoptando la forma de una crítica unilateral a la falta de carácter de la Modernidad, entendida como constante vaivén de las opiniones y ausencia de un centro regulador de las fluctuaciones de la persona ${ }^{28}$, poco a poco se va precisando en términos más complejos. Nietzsche no se limita a denostar un estado de cosas caracterizado por el veloz intercambio de roles sociales. Se preocupa más bien de que, en medio de esta situación, en lugar de trabajar en pro de nuevas formas de construcción social que garanticen elevación cultural, el individuo se abandone al desaliento o se tome a sí mismo como fin último, hipostasíe su condición de portador de máscaras, entendiéndose como sustrato último de las mismas, y, en consecuencia, bloquee la genuina dimensión liberadora que podría tener este proceso de desustancialización de la identidad del sujeto. Cabe observar aquí una significativa analogía con el tipo de crítica formulada por Hegel contra la ironía romántica, a la cual le reprocha el no ampliar su proceso disolutivo de valores y verdades al propio sujeto que la ejerce, permaneciendo éste entonces férreamente anclado en su "sí mismo» y preservándose como yoidad que juguetea con el mundo: algo que Wagner ha hecho siempre, al salvar «la tendencia 'demoníaca' a la despersonalización de su transmutarse en juego gracias al recurso a la 'serenidad' del texto poético»" ${ }^{29}$.

Así pues, bien porque el actor se identifica plenamente con el trasfondo metafísico de la vida y se convierte en su médium, bien porque se toma a sí mismo como sujeto que controla y modula el juego escénico, pero no acepta sumergirse en él hasta disolver su propia consistencia, en ambos casos, la concepción wagneriana permanece dentro de la órbita romántico-idealista. La subjetividad fuerte del genio wagneriano se mantiene al margen de la disolución genealógica y se toma a sí misma como principio, no como resultado, siempre provisional, de todo un largo trabajo de cultivo de múltiples impulsos y aptitudes. Y esto es lo que lleva al último Nietzsche a denunciar el histrionismo de Wagner, por si-

26. Cf. KSA II 623-624. Los términos de la polémica con el «Cagliostro de la Modernidad» en El caso Wagner recogen directamente este planteamiento.

27. «El carácter demagógico y la intención de influir sobre las masas son actualmente comunes a todos los partidos políticos» (KSA II 285; HH I 215).

28. Cf. $v$. g. la caracterización de Wagner como un névrose en el parágrafo quinto de El caso Wagner (KSA VI 21-23).

29. G. Campioni, Sulla strada di Nietzsche, Pisa: ETS, 1992, p. 205. Campioni contrapone en este punto el planteamiento expuesto por Wagner en su escrito Über Schauspieler und Sänger (Gesammelte Schriften..., cit., vol. IX, pp. 251 ss.) y las formulaciones nietzscheanas de «La visión dionisíaca del mundo». 
mular un abandono al fondo pulsional primordial, que no deja de ser en ningún instante una maniobra cerebralmente calculada por el artista, quien finge una inmediatez imposible y trata de hacerla pasar por un contacto transparente con la verdad ${ }^{30}$. Wagner miente así sobre la mentira inherente a todo arte, al querer hacer de él órganon de una verdad más alta. Pero adviértase que con semejante estilo de crítica, que no se formula desde una instancia superior de sentido y verdad, sino desde la comprensión del carácter mismo de fabulación que acompaña al arte, Nietzsche tampoco puede quedar completamente al margen de la historia de este error. En coherencia con tal reconocimiento de la necesidad de aplicar el proceso de análisis y disolución del sustrato metafísico de nuestras certezas al propio sujeto, Nietzsche se confiesa él mismo un décadent, en tanto en cuanto es alguien que también ha sido conformado por la experiencia de la enfermedad.

Esto establece la principal diferencia entre el tipo de crítica de la cultura formulada por el joven Nietzsche, cuya intempestividad se confundía y entremezclaba aún con el recurso a un absoluto Afuera romántico para legitimarse (la Grecia trágica, el Uno primordial), y la crítica genealógica que comienza a despuntar a partir de Humano, demasiado humano. Tras el alejandrinismo denostado en El nacimiento de la tragedia, el escepticismo pasa a ser el primer término de análisis de todos esos caracteres de la cultura moderna que luego condensará Nietzsche bajo el concepto de nihilismo. Si de éste dirá más tarde, con razón, que se trata de un fenómeno ambiguo, no menos ambiguo se le presenta desde un principio el talante escéptico de su época. Nietzsche no lo reduce en ningún caso a un expediente meramente gnoseológico, sino que lo examina como un asunto esencialmente relativo a modos de conducta y criterios de valoración. La cuestión que le preocupa en primera instancia es la de cómo habrá de configurarse la sociedad bajo el influjo de la actitud escéptica que poco a poco se va extendiendo por doquier, a raíz de la falta de fe en la existencia de un mundo metafísico. La correlación entre estos dos planos, crítica de la metafísica y problema axiológico, es completamente diáfana en el capítulo primero de $\mathrm{Hu}$ mano, demasiado humano, y domina el conjunto de la meditación desplegada a lo largo de todo el libro. Nietzsche ve una seria dificultad en la desaparición de la creencia de que es posible conocer el fundamento último sobre el cual ha de basarse y erigirse el futuro de la humanidad: el individuo tiende entonces a constreñir demasiado su mirada al corto espacio de tiempo de su vida particular y no se siente con fuerzas para proyectar obras colectivas de largo alcance ${ }^{31}$. Nietzsche, que por supuesto tampoco cree en la posibilidad de floraciones inmediatas y espontáneas de una cultura superior, sino en el producto de una ardua tarea de crianza y adiestramiento de generaciones, plantea ahí la cuestión de si el hombre moderno, entregado en exceso a demasiadas evoluciones, experiencias y exploraciones, no estará necesitado de compensar su efímera existencia con esa clase de reposo de largo aliento que fue propio de épocas pasadas. De nuevo se suscita en este punto la sospecha de si acaso la alternativa vislumbrada por el filósofo no habrá acabado resolviéndose en un intento de recuperación

30. Sobre la teatralidad de Wagner, al poner aparentemente en escena «la música como Idea» para revelar al fin un automatismo efectista, cf. KSA VI 26-29 y 36-39.

31. Cf. los aforismos «Presunta victoria del escepticismo» $\mathrm{y}$ «Falta de fe en el monumentum aere perennius» (KSA II 42-44). 
de los viejos asideros de la tradición, o tal vez en la paradoja de una metafísica de nuevo cuño que, incapaz de sobreponerse al descrédito nihilista de todo metarrelato, ha debido optar, con pragmático cinismo, por la imposición arbitraria de la voluntad de quienes detentan el poder. Sólo que Nietzsche no se engaña respecto a la irreversibilidad de este proceso corrosivo de las firmes cadenas de antaño. La nuestra, escribe en otro aforismo de Humano, demasiado humano, es una «época de la comparación», en la que "pueden contrastarse y vivirse unas junto a otras las distintas concepciones del mundo, costumbres, culturas» (KSA II 44), lo cual la desliga de la tradición más de lo que nunca antes lo estuvo época alguna. «Éste es su orgullo», prosigue, "pero, para ser justos, también su desgracia». Ahora bien, aun cuando Nietzsche advierte el peligro de esta posición de extremo desasimiento, concluye en este caso:

iNo temamos esta desgracia! Queramos más bien entender tan generosamente como podamos la tarea que nos fija la época: por ello nos bendecirá la posteridad, una posteridad que se sabe por encima tanto de las cerradas culturas populares originales como de la cultura de la comparación, pero que vuelve agradecida la vista atrás hacia ambas clases de cultura como hacia venerables antigüedades ${ }^{32}$.

En su «Ojeada al Estado» del capítulo octavo de esa misma obra, Nietzsche insiste en este planteamiento, según el cual:

la subordinación, tan altamente estimada en el Estado militar y burocrático, no tardará en hacérsenos tan increíble como ya se ha hecho la hermética táctica de los jesuitas; y cuando ya no sea posible, dejará de lograrse una gran cantidad de efectos asombrosos y el mundo se empobreceráa ${ }^{33}$.

Una vez más, si leyéramos a Nietzsche hasta aquí o nos fijásemos tan sólo en alguno de esos fragmentos póstumos en donde se limita a apuntar esta idea, sin desarrollarla hasta el final, perderíamos de vista lo que suele añadir a este primer momento de su consideración: la convicción de que esta subordinación, según afirma a renglón seguido,

debe desaparecer, pues desaparece su fundamento: la fe en la autoridad absoluta, en la verdad definitiva; incluso en los Estados militares, para producirla no basta la coacción física, sino que es menester la inveterada adoración de lo principesco como algo sobrehumano.

Y, una vez más, concluye: «En situaciones de mayor libertad, uno sólo se somete bajo ciertas condiciones, como consecuencia de un mutuo acuerdo, es decir, con todas las reservas del propio derecho».

Como estamos viendo, al interpretar sus frecuentes reparos y objeciones al curso de esta Modernidad escéptica como si se tratase de un rechazo frontal y una impugnación absoluta de la misma, se olvida hasta qué punto Nietzsche ha asumido ya la imposibilidad de situarse en una posición completamente externa a la "decadencia», para juzgarla desde fuera, como una totalidad de signo negativo. Ya en un fragmento de 1875, curado de la grecomanía exhibida en El 
nacimiento de la tragedia, Nietzsche señala que «nos separa para siempre de la cultura antigua el que su fundamento se ha convertido definitivamente en algo caduco para nosotros» (KSA VIII 83). A eso añade que «ni lo griego ni el cristianismo y los fundamentos que han sostenido hasta el presente nuestra sociedad y nuestra política, se pueden recuperar». A partir de entonces, los contrastes establecidos en su obra entre el pasado griego y el propio tiempo se tiñen por entero del sentido más cabal de la intempestividad: se ejercen para dislocar el presente y abrirlo a tendencias que contrastan con un mostrenco apego a lo dado, descubriendo en él —no antes, ni después, en un sentido utópico- otros valores. En ese cruce intempestivo confluyen para el filósofo el espíritu trágico-dionisíaco y el espíritu libre de «los buenos europeos»"

Nietzsche interpreta, pues, desde dentro de la propia dinámica nihilista de la Modernidad, mas tratando de avistar ahí y promover aquellas orientaciones que puedan resultar más estimulantes para la vida y el desarrollo de una cultura afirmativa, emancipada de la manía de trasmundos y del lastre ascético impuesto por el cristianismo a la vivencia de la corporeidad y contingencia humanas. Por eso le preocupa que el escepticismo pueda quedar fijado en su configuración primera, que se mantenga apegado aún a la nostalgia del ideal, al estilo apreciativo de las viejas tablas y confunda por ello su sentido, se vuelva inseguro respecto de sí mismo, se avergüence del campo de posibilidades que abre a la voluntad de proponerse nuevas metas y trate de paralizar dicha voluntad, escudándose en el disfraz del objetivismo, de la neutralidad científica, de l'art pour l'art y tantos otros calmantes de la inquietud y zozobra que es preciso afrontar en un mundo dejado de la mano de Dios ${ }^{35}$. No obstante, pese a estas cautelas, Nietzsche no renuncia al cometido de la crítica genealógica, que no es otro que el de infectar de escepticismo, esto es, de desconfianza crítica, nuestro modo de relacionarnos con las verdades establecidas para comprenderlas en su carácter históricamente contingente. Esta desconfianza crítica es la que surge precisamente del «sentido histórico», y es ilustrativo volver a comprobar cómo a propósito del mismo, en plena etapa intermedia e inmediatamente después de la publicación de Humano, demasiado humano, Nietzsche sigue mostrando unas ambivalencias que no aspira en absoluto a resolver de modo unilateral. Así, en el parágrafo 337 de La gaya ciencia, leemos:

Considerando la época actual con los ojos de otra venidera, no se descubre en el hombre de hoy nada más extraño que su peculiar virtud y enfermedad, denominada «el sentido histórico». Se trata de un impulso hacia algo totalmente nuevo y desconocido en la historia: si se concediesen a este germen algunos siglos o más, de él podría desarrollarse finalmente una planta maravillosa, con una fragancia no menos maravillosa, por la que vivir en esta vieja tierra sería más agradable que anteriormente. Los hombres presentes empezamos justamente a forjar la cadena de un futuro sentimiento muy poderoso, eslabón por eslabón — sin darnos cuenta

34. Sobre esta cuestión, cf. F. Duque, «Retrogriego, apátrida, proeuropeo»: Sileno. Variaciones sobre arte y pensamiento 8 (2001), 7-23.

35. Cf. KSA V 138-139. Pasajes como éste del aforismo 208 de Más allá del bien y del mal testimonian una continuidad temática con las reflexiones expuestas por Nietzsche durante las obras del período intermedio. De hecho, los primeros apuntes preparatorios de este libro, publicado en 1886, se remontan a 1881 . 
de lo que estamos haciendo. Casi nos parece que no se tratara de un sentimiento nuevo, sino de la merma de todos los sentimientos antiguos - el sentido histórico es aún una cosa muy pobre y fría, y muchos se quedan sorprendidos ante él como ante una helada, y por él se hacen más pobres y fríos (KSA III 564; GC 244-245).

Virtud y enfermedad no se oponen aquí según férreos términos dualistas. Nietzsche avisa de nuevo de que quienes sientan meramente como vaciado y empobrecimiento el estado actual de desvalorización de los valores antaño tomados como absolutos, se volverán ellos mismos pobres y fríos, incapaces de crear. De ahí el sentido de esos otros pasajes en que contrapone la paralización escéptica de la voluntad a la filosofía del futuro ${ }^{36}$. Ahora bien, observa asimismo que la virtud creadora y transvaloradora ha de surgir de idéntico suelo al de la "enfermedad histórica». No se trata de crear en abstracto y desde una presunta libertad ilimitada, sino a partir de las condiciones concretas del momento. En ese sentido, en el texto citado, Nietzsche problematiza lo que constituye el arranque de su nuevo estilo de filosofar, presentando su lado negativo. Pero ya no apela como remedio a potencias eternizadoras, suprahistóricas, según hiciera en la segunda Intempestiva. En coherencia con el punto de vista defendido ya en $\mathrm{Hu}$ mano, demasiado humano, se trata, en cambio, de potenciar ese ejercicio disolutivo de certezas que parecían inconmovibles (como la de la felicidad ultraterrena o el progreso necesario de la especie); de saber soportar la tremenda aflicción que dicho ejercicio comporta, mientras dura la convalecencia y el aprendizaje de una nueva, gran responsabilidad: la de que ahora «los hombres pueden decidir conscientemente seguir desarrollándose hacia una nueva cultura» ${ }^{37}$.

Para concluir este aspecto de mi argumentación, me remitiré a otro parágrafo de La gaya ciencia en el que puede observarse igualmente, en su rico despliegue de matices, el curso de este movimiento del pensar nietzscheano. El aforismo en cuestión lleva por título «Diferentes formas de descontento». Su tema es el de los distintos modos de afrontar el trato con la vida. A ello añade Nietzsche una consideración sobre la manera en que estas formas de descontento han influido en la cultura europea. Inicialmente, pues, nos encontramos con una exposición de ambas modalidades:

Los descontentos débiles y cuasi femeninos son los que tienen inventiva para el embellecimiento y profundización de la vida; los descontentos fuertes —los masculinos entre ellos, para seguir con la misma imagen- para el mejoramiento y afianzamiento de la vida. Aquéllos revelan su debilidad y femineidad en que les

36. Para un análisis detallado de los diferentes sentidos que el término «escéptico» ha ido adoptando en el pensamiento nietzscheano, cf. J. B. Llinares, «Nietzsche y el escepticismo. Ensayo aclaratorio de una pretendida contradicción», en J. Marrades y N. Sánchez Durá (eds.), Mirar con cuidado. Filosofía y escepticismo, Valencia: Pre-Textos, 1994, pp. 87-105.

37. Concluye Nietzsche el aforismo titulado «Posibilidad del progreso», del que está tomada la cita supra, con las siguientes palabras: «es precipitado y casi sin sentido creer que el progreso debe tener lugar necesariamente; pero ¿cómo podría negarse que es posible? No es en cambio ni siquiera pensable un progreso en el sentido y por el camino de la cultura antigua. Aunque el fantaseo romántico aplica constantemente la palabra ‘progreso' a sus metas (por ejemplo, cerradas culturas populares originales), en todo caso toma prestada la imagen del pasado: su pensamiento y su representación carecen de toda originalidad en este dominio» (KSA II 45; HH I 57). 
gusta dejarse engañar de vez en cuando y alguna vez se contentan acaso con un poco de embriaguez y exaltación, pero en un plano general no pueden ser satisfechos y sufren de esta satisfacción incurable; por lo demás, apoyan a todos los que saben ofrecer consuelo opiado y narcótico y, en consecuencia, ven con malos ojos a quienes ponen al médico por encima del sacerdote - iasí ayudan a la continuación de las verdaderas calamidades! (KSA III 398; GC 84-85).

De lo expuesto hasta aquí parece posible colegir, por tanto, que Nietzsche privilegia la forma fuerte, masculina, viril, de descontento, mientras que condena la forma débil, femenina, permanentemente insatisfecha, inquieta e incurable. ¿Acaso no resuena en tales palabras el Nietzsche de la cruda voluntad de poder, que impone un sentido al devenir múltiple y lo afianza frente al riesgo de disipación nihilista? Pero dejemos que sea el propio Nietzsche quien nos responda. Acto seguido, escribe:

Si no hubiesen abundado en Europa desde los tiempos medievales los descontentos de este tipo [femenino], tal vez no se hubiese desarrollado la famosa facultad europea de transformación permanente: pues las exigencias de los descontentos fuertes son demasiado toscas y, en el fondo, demasiado modestas como para no poder ser satisfechas alguna vez. China es ejemplo de un país donde el descontento en grande y la facultad de transformación se han extinguido desde hace muchos siglos, y los socialistas y los idólatras del Estado, con sus medidas tendentes a mejorar y afianzar la vida, podrían fácilmente depararnos un estado de cosas chino y una «felicidad» china, siempre que puedan previamente extirpar aquí ese descontento y romanticismo de tipo más enfermizo (KSA III 398-399; GC 85).

Se podrá decir, no sin cierta dosis de razón, que es el gusto nietzscheano por la paradoja lo que le lleva aquí a exagerar sus simpatías hacia el romanticismo, respecto del cual volverá sin duda a marcar distancias en otros textos. Pero hemos examinado ya el carácter de la crítica nietzscheana con el mínimo de detalle suficiente como para comprender que Nietzsche no incurre aquí en una contradicción. El debilitamiento de la rigidez de los viejos valores es apreciado por él por encima de la ciega subordinación a las costumbres heredadas. La visión monolítica de la organización social proporciona una seguridad y felicidad «chinescas», que los idólatras modernos del Estado-nación, herederos de la voluntad redentora del cristianismo, han asumido acríticamente. De modo que, frente al optimismo superficial que se desprende de esta maquinaria estatal, que hace del individuo mero engranaje del sistema, Nietzsche valora la sospecha romántica, por no contentarse tan fácilmente con las promesas de un mundo mejor y seguir denunciando la insuperabilidad del dolor de la existencia. En cuanto disolutivo de la engañosa consistencia de aquel mundo feliz, el elemento enfermizo del hombre europeo es afirmado sin tapujos por Nietzsche en un párrafo final del citado aforismo, que representa una genuina transvaloración: «Es Europa una enferma que debe máxima gratitud a su incurabilidad y a la transformación sempiterna de su dolencia».

Nietzsche, en efecto, es verdaderamente transvalorador ahí donde alcanza a poner en cuestión las dos direcciones reactivas fundamentales por las que ve encaminarse al hombre europeo - hacia una masa de trabajadores locuaces, apáticos y sumamente eficientes, necesitados de un amo, por una parte; o hacia una serie de tipos morbosos, ávidos de sensaciones extremas, de consuelo y nar- 
cóticos para soportar su doliente existencia, por otra- y, a pesar de ello, sabe extraer de sus fallas, de sus desechos, la posibilidad de un über. En el fondo, a mi modo de ver, las mejores enseñanzas las ha obtenido Nietzsche de su convalecencia de la enfermedad estética. En la vertiente política, su aristocratismo ha sido en el fondo menos radical, más apegado al prejuicio de que, sin un cierto tipo de esclavitud, no hay cultura superior ${ }^{38}$. Su crítica a la reproducción mecánica del hombre-masa en la sociedad europea de su tiempo lo ha llevado a una condena demasiado sumaria del proceso de democratización, sobre todo en algunos escritos de los últimos años, en donde se producen divergencias respecto a la línea argumental que hemos reconstruido aquí, línea que conduce de hecho a la conclusión que Nietzsche formula ya de manera explícita en sus años de librepensador apátrida: el escepticismo democrático es un resultado de la mezcolanza de razas, valoraciones y concepciones del mundo, que concede a la Europa actual, en su condición de enferma incurable de esta dolencia, las ventajas de una amplitud de miras y una capacidad de transformación y experimentación muy superiores a la de otras culturas:

El comercio y la industria, el tráfico de libros y cartas, la comunalidad de toda la cultura superior, el rápido cambio de lugar y paisaje, la actual vida nómada de todos los que no poseen tierras, estas circunstancias comportan necesariamente un debilitamiento y, por último, una destrucción de las naciones, al menos de las europeas: de modo que de ellas debe nacer, como consecuencia de los continuos cruces, una raza mixta, la del hombre europeo (KSA II 309; HH I 230).

Sin embargo, a pesar de que la democracia se presente así como una forma de organización política coherente con el creciente descreimiento de la mentalidad moderna ${ }^{39}$, Nietzsche no parece valorarla demasiado en ese sentido. Ya hemos visto, en el caso del escepticismo, que el filósofo lo aprecia justo en la medida en que su debilitamiento del elemento rígido, estático, de los códigos y normas de organización social no deriva hacia un pesimismo estéril y hacia una incapacidad para aventurarse en lo nuevo. Si, por el contrario, la actitud escéptica se agota en sí misma, no comprende su remisión a un contexto previamente dado ni cede el paso a un nuevo estilo de filosofar crítico-experimental, entonces, su miedo ante la responsabilidad la induce de nuevo a esconderse tras la colectividad y a alimentar un espíritu gregario (KSA V 138-139). Y esto es lo que Nietzsche ha notado acentuarse de forma palmaria con el democratismo. Su visión de la democracia, siendo en todo momento una crítica de la sociedad de masas por su conciencia gregaria, su moral de rebaño, su negación de la excelencia, su disfrute de la mediocridad, su cultura periodística, su humanitarismo hi-

38. Y ello por más que en diferentes textos matice, en efecto, el sentido de ese «cierto tipo de esclavitud» o «nueva forma» de la misma, homologándola sencillamente con las condiciones actuales de vida de la masa trabajadora. Así, en el aforismo 283 de $\mathrm{HH}$ : «Como en todas las épocas, así también hoy en día todos los hombres se dividen en esclavos y libres; pues quien no tiene para sí dos tercios de su día, es un esclavo [Sclave]»(KSA II 231-232). Para las implicaciones de la distinción terminológica entre Verknechtung y Sklaverei, véase la interesante nota 16 del artículo de F. Duque antes citado, p. 18.

39. Cf. $v$. g. el fragmento 34[67] de 1885, en el que Nietzsche se refiere a "nuestra húmeda época de aire democrático» y que comienza así: "Nuestra época es escéptica en sus instintos más esenciales» (KSA XI 440-441). 
pócrita y su amodorramiento burgués, no ha consentido explorar la posibilidad de que ese "caos cosmopolita de afectividad e inteligencia» (KSA XIII 17) que estaría llegando a ser el europeo pudiese subvertir dicho orden de cosas sin el concurso de una raza fuerte de señores. La principal preocupación de Nietzsche, con todo, ha seguido siendo aquí la misma que hemos ido desentrañando a lo largo de las páginas precedentes: evitar la supeditación del individuo a una maquinaria estatal totalizadora del sentido de su existencia. Dicho sea de paso, éste es también el motivo por el que el filósofo tiende a abandonar la predilección por la ciencia manifestada en las obras del período intermedio, conforme observa que el enfoque positivista cada vez más extendido reintroduce un superficial optimismo y un objetivismo falaz en el conocimiento científico, asociándolo a un dispositivo técnico cuya verdadera consecuencia es el aumento de mecanismos de gregarización ${ }^{40}$. En todos estos casos, resulta bastante discutible dar sin más por sentado que la orientación última de Nietzsche se reduce a la búsqueda de un principio unificador que elimine la diversidad e instaure un sentido global al caos cosmopolita de la vida moderna. En particular, me parece sumamente erróneo interpretar la estética fisiológica del último Nietzsche como una mera propuesta de restricción clasicista a la celebración romántica de la dispersión de los instintos. Entre quienes repudian en su pensamiento político una contaminación esteticista, no sólo se cuentan los que le atribuyen la típica salida irracionalista de la inmediatez romántica, sino también los que le achacan la no menos irracional, por arbitraria y fundada únicamente en la fuerza del genio-tirano, imposición del «gran estilo», entendiendo por tal un sojuzgamiento de la multiplicidad de impulsos. Mas, como estamos viendo, el diagnóstico nietzscheano sobre la crisis de la Bildung es más elaborado y está dotado de un espesor teórico que lo distingue tanto de la simple contraposición entre una cultura humanista idealizada y una decadente civilización tecnocientífica, cuanto del nostálgico intento de restaurar una totalidad perdida. Antes que pretender desterrar al artista trágicodionisíaco lejos de la república, quizá mereciera la pena intentar que su proximidad contaminase a esa figura de la gran política nietzscheana todavía demasiado similar a la del filósofo-tirano platónico ${ }^{41}$. Pues precisamente es en el terreno del

40. Recogiendo un aspecto que estaba ya presente en el escrito Sobre verdad y mentira en sentido extramoral, Nietzsche señala el instinto gregario que domina en el conocimiento científico: «Se fija la uniformidad de las sensaciones y el gusto normal en todas las cosas. Así, el conocimiento, fundándose en la fe en lo que es y persiste, está al servicio de la técnica, de la masificación» (KGW $\mathrm{V} / 2$ 386-387).

41. De la concepción energetista de la voluntad de poder que predomina en los fragmentos póstumos de los años 1885-1886 se transita en los años 1887-1888 a una modulación preferentemente "hermenéutica», en donde la voluntad se pluraliza y se concibe a partir del conflicto entre diversas interpretaciones. En coherencia con este punto de vista, las apelaciones nietzscheanas al pólemos como elemento agitador de la modorra existencial en que se halla sumido el hombre moderno parecen orientarse más bien a la idea de un contraste entre diferentes concepciones del mundo, antes que a un enfrentamiento violento. Nietzsche trata de concretar sobre todo en el arte este modelo hermenéutico de la voluntad de poder, mientras que sus consideraciones sobre la gran política siguen prendidas aún en buena medida de fantasías como la del filósofo-legislador o la de un tipo aristocrático de gobierno importadas de su imagen del mundo clásico a través del filtro de autores como Jacob Burckhardt. Resulta interesante considerar a este respecto la manera en que Nietzsche se ha representado en sus lecciones introductorias al estudio de los diálogos platónicos de los años 18711872 la figura del gran filósofo griego que luego le sirviera como antagonista metafísico: Platón es mostrado ahí como un pensador eminentemente político, cuyo principal objetivo es la promoción 
arte donde el ensayo nietzscheano de una asunción transvaloradora de la decadencia se ha desarrollado con mayor hondura en el sentido de un movimiento inmanente a la misma, que ha seguido siendo fiel al espíritu antidogmático del perspectivismo y de la relativización genealógica del valor de los valores. Ahí es donde Nietzsche ha asumido con mayor coherencia el abandono de la fe juvenil en una totalización de la experiencia moderna bajo una «unidad de estilo». No puede decirse lo mismo, en efecto, de sus consideraciones en el terreno político. Pero como vamos a ver para concluir, en el arte sí ha explorado Nietzsche esa posibilidad de apertura sin resto y ha terminado aceptando el envite, los riesgos de este ejercicio disolutivo, sin regresar a una posición fuerte de dominio. La unidad que el gran estilo establece se sabe al fin convencional y, por consiguiente, precaria. Se presenta, pues, como un modo de ordenar la multiplicidad de la experiencia que ya no aspira a anular su carácter variopinto. Sólo en esta medida alaba Nietzsche la fuerza organizadora del arte, mientras sigue criticando con aspereza la teatrocracia wagneriana, como ya hiciera en los apuntes preparatorios de la tercera Intempestiva, por su empeño en simplificar la complejidad del mundo y halagar directamente el gusto de las masas. Al énfasis histriónico del comediante Wagner, que busca a la postre salvar su alma dispersa en un consuelo metafísico y hacerla reposar en un sólido fundamento, contrapone el último Nietzsche la figura del filósofo-artista, que acoge productivamente en sí una multiplicidad de almas mortales y halla en la imposibilidad de conciliarlas definitivamente la oportunidad de experimentar una sobreabundancia de vida. Mas esta contraposición se plantea ya en el espacio interno, artificioso y mestizo, de la décadence. Como han mostrado de manera rigurosa Mazzino Montinari y, tras sus pasos, Giuliano Campioni, las discrepancias entre la valoración de la decadencia parisina que Nietzsche lee en los Ensayos de psicología contemporánea de Paul Bourget, quien reprueba por completo la contradicción fisiológica de estos temperamentos morbosos, y su propio punto de vista al respecto, que detecta ahí, además, una vía posible hacia el ensayo de nuevas formas de enriquecimiento vital, atestiguan que el interés manifiesto del filosofar nietzscheano sigue siendo también en este punto el de quebrar la estabilidad, fijeza y aseguramiento metafísicos de la posición de dominio adoptada por el sujeto a lo largo de la historia de Occidente ${ }^{42}$. La observación histórica y psicológica del carácter de constructo del yo, puesta en relación con el problema de la aceptación del descrédito de los valores transcendentes, ha llevado a Nietzsche a un examen de la extrañeza y pluralidad que nos constituye, hallando en el ámbito del arte uno de los lugares más destacados donde desarrollar sus análisis. Con ello, Nietzsche

de los medios adecuados para instaurar una organización estatal basada en un sistema de castas: «ein Kastenstaat» (KGW II/4 61).

42. De G. Campioni, cf. «Fisiologia dell'arte e della decadenza», en el ya citado Sulla strada di Nietzsche, pp. 221-250. De M. Montinari, «Aufgaben der Nietzsche-Forschung heute: Nietzsches Auseinandersetzung mit der französischen Literatur des 19. Jahrhunderts", en S. Bauschinger, S. L. Cocalis y S. Lennox (eds.), Nietzsche heute. Die Rezeption seines Werkes nach 1968, Bern/Stuttgart: Francke, 1987. Montinari explica ahí cómo la densa labor de reescritura a la que Nietzsche somete algunos fragmentos póstumos y pasajes de obras anteriores en su Nietzsche contra Wagner permite comprender cómo, a un nivel más profundo, su polémica con Wagner no se reduce a una simple caracterización de antípodas, antes bien, opera bajo el supuesto de su común afinidad con muchos de los rasgos de esa cultura parisina del XIX en la que florece el fenómeno de la decadencia. 
no se ha apartado, en efecto, del impulso crítico de su librepensamiento, sino que ha tratado más bien de culminarlo, en el mismo sentido en el que expresó la diferencia entre el esprit fort dieciochesco y el suyo: «La figura del espíritu libre quedó inacabada en el siglo pasado: ellos [los esprits forts] negaron aún demasiado poco y se conservaron a sí mismos» (KSA VIII 295). Consideremos, pues, finalmente cómo ha formulado la meditación estética de Nietzsche esa pérdida de la identidad fuerte del sujeto y la consiguiente fragmentación y quiebra interna de todo «gran estilo».

Hay una faceta del diagnóstico nietzscheano sobre la posibilidad del arte surgido en el contexto del nihilismo que suele quedar relegada en favor de la caracterización más frecuente de sus propuestas como las propias de una estética del gran estilo y de la fuerza uniformadora. Esta caracterización más convencional es la que hallamos también, aunque con matices, en diversos pasajes del curso impartido por Heidegger en el semestre de invierno de 1936-1937 y que lleva por título La voluntad de poder como arte. El gran estilo aparece descrito ahí como la manifestación estética de la voluntad de poder, como consecuencia de una fuerza acrecentada y, por consiguiente, como contramovimiento opuesto al nihilismo, que embellece la existencia a base de dominar su íntima contradictoriedad y complejidad, simplificándola bajo una forma unitaria. Todos ellos son términos que se encuentran efectivamente en los fragmentos póstumos del filósofo, pero que aquí son leídos por Heidegger en el sentido de su confrontación con Nietzsche como pensador metafísico. Por eso, aunque Heidegger matiza que, al asociar el arte del gran estilo con el gusto clásico, Nietzsche no cae en un clasicismo y un humanismo convencionales, considera que el gran estilo, interpretado como voluntad de imposición de una forma al caos fenoménico, es para él la esencia propia del arte, al margen de cualquier precisión histórica. De ahí resultaría la oposición nietzscheana al arte romántico wagneriano en cuanto arte decadente, de la disgregación de las formas y la completa disolución del estilo, capaz de crear sólo de manera reactiva, a partir del descontento y el deseo de huir de la realidad.

No obstante, esta aproximación a la meditación nietzscheana sobre el arte nos parece insuficiente. Heidegger difumina una distinción no menos básica establecida por Nietzsche entre la creación artística procedente del anhelo de volverse rígido, de volverse eterno, en suma, del «anhelo de ser» y la procedente del anhelo de destrucción, de cambio, de devenir, siendo tal distinción la que mejor explica el rechazo nietzscheano del idealismo wagneriano: no porque éste sea ficción, puesto que es prerrogativa de toda creación artística transfigurar la realidad, sino porque trata además de encubrir dicho carácter ficcional de la obra de arte, poniéndola al servicio de la Idea, convirtiéndola en vehículo de una verdad intemporal e intentando ocultar así la índole nihilista de su propia época, de una Modernidad que ya habría dicho adiós a toda pretensión metafísica y habría aceptado el rango experimental, hermenéutico, precario y en devenir de nuestras verdades. Pero entonces la controversia con Wagner por producir un arte que finge el gran estilo y mediante ese fingimiento reactivo de la ficción 
activa cierra los ojos a la circunstancia de que el nihilismo ya se ha hospedado en la Modernidad adquiere una dimensión histórica, que Heidegger no ha tenido suficientemente en cuenta y que problematiza la idea de que el gran estilo sea para Nietzsche la esencia y, por tanto, el único destino afirmativo del arte moderno. De hecho, en el fragmento póstumo de la primavera de 1888 numerado por Colli-Montinari como 14[61] y que lleva el encabezamiento «Voluntad de poder como arte. Música y gran estilo» (KSA XIII 246-248), al contrario de lo que observa Heidegger en su comentario al mismo, sí que se trata de la cuestión histórica de si hasta ahora el gran estilo ha estado más o menos presente en la música ${ }^{43}$. Heidegger no contempla esta posibilidad, porque sigue pensando que Nietzsche busca también para el arte del futuro ese gran estilo, que no halla en la música. Sin embargo, en este y otros textos de la última época, que contrastan con aquellos que defienden más bien un "clasicismo de la fuerza», Nietzsche modula sus ideas al respecto, insertándolas en el panorama de un mundo tan abigarrado como el moderno, al que no sólo no cabe ya asignar perfiles definidos, sino donde se ha vuelto enormemente problemático negar la evidencia de la disolución de la forma clásica. Esto es lo que plantea el fragmento mencionado: si todas las artes conocen esa ambición, propia del gran estilo, de «dominar el caos que se es, de obligar al propio caos a convertirse en forma: a ser lógico, simple, unívoco, matemática, ley», «¿ipor qué falta en la música?» (KSA XIII 247). ¿Acaso porque no corresponde a su esencia, como sugiere Heidegger, haciendo del predominio de la música en el romanticismo wagneriano un síntoma de «una posición fundamental de tipo estético respecto al arte en su conjunto", consistente en «la concepción y valoración del arte desde el mero estado sentimental y de la creciente barbarización de este último, que lo convierte en la mera ebullición del sentimiento abandonado a sí mismo?» ${ }^{44}$. Si así fuera, añade Heidegger, «puesto que Wagner buscaba meramente la ascensión de lo dionisíaco y desbordarse en él, mientras que Nietzsche quería sujetarlo y conformarlo, la ruptura entre ambos estaba ya predeterminada». Pero no es esto lo que plantea Nietzsche en ése y otros fragmentos de la última época, donde se refiere al gran estilo más como una aspiración del arte que como una presunta esencia del mismo, y donde no postula domeñar el impulso dionisíaco bajo una bella forma, según lo interpreta Heidegger en pos de su identificación de la voluntad de poder con una última modalidad de la subjetividad dominadora de la metafísica, sino hacer del arte el lugar de desbordamiento de esos poderes corporales exuberantes (sensualidad, ebriedad) que tienden a aflorar mediante una multitud de medios expresivos ${ }^{45}$. Nietzsche aprecia la fuerza configuradora del gran estilo, pero sabe también, como escribe en El caso Wagner, que la vida ya no reside en la totalidad, que la unidad está rota y sólo puede reconstruirse de manera puramente convencional y arbitraria. Por eso, lo que plantea en el fragmento 14[61] es si la decadencia del

43. Cf. M. Heidegger, Nietzsche: der Wille zur Macht als Kunst, en Gesamtausgabe, Frankfurt a. M.: Klostermann, vol. 43, 1985, p. 157. A diferencia de otros pasajes que citamos a continuación, éste no está recogido en la versión anterior de este curso incluida por Heidegger en su Nietzsche (Pfullingen: Neske, 1961).

44. M. Heidegger, Nietzsche, trad. de J. L. Vermal, Barcelona: Destino, 2000, vol. I, p. 92.

45. Gianni Vattimo ha defendido de manera convincente esta interpretación en su ensayo «La voluntad de poder como arte», recogido en su libro Las aventuras de la diferencia. Pensar después de Nietzsche y Heidegger [1980], Barcelona: Península, 1985, pp. 85-107. 
gusto clásico en la música de su tiempo no estará anticipando tal vez otro estilo de cultura, aquella en la que, como leemos ahí, "ya ha concluido el reinado de todo tipo de hombre de la violencia». No se trata, por tanto, de que Nietzsche niegue a toda la música, por su esencia, la posibilidad del gran estilo, sino de que, analizando su concreto discurrir histórico de Mozart a Wagner, observa cómo ésta ha llegado a configurarse en su época como una especie de «contrarrenacimiento» y como una despedida del clasicismo. Sólo que esta situación ya no es valorada por él en términos meramente negativos. De este y otros textos póstumos de los años 1888-1889 se desprende, por el contrario, la conclusión de que Nietzsche ha llegado a admitir finalmente como un factor positivo del arte moderno la dispersión y experimentación estilísticas, así como la explotación de esos estados de extrema excitabilidad y agudeza de los sentidos, que tanto se asemejan a los estados morbosos —en la delectación en los detalles, en la embriaguez y en el desbordamiento corporal - y que atestiguan la imposibilidad de encerrar los movimientos del yo bajo una única forma integradora ${ }^{46}$. También el arte, en fin, experimenta así la pérdida de un centro fijo de referencia —eso que Nietzsche ha denominado la muerte de Dios- como caída hacia ningún lugar, como composición arbitraria de signos en la palabra poética, como relatos que no hablan de nada en la literatura, como quiebra del discurso tonal en la música, como emergencia de manchas y trazos dispersos en el lienzo, etc. En consecuencia, de las dos notas que Heidegger señala como principales motivos de la crítica nietzscheana a Wagner, su falta de auténtico estilo y su deslizamiento hacia un cristianismo moralizante y falaz ${ }^{47}$, sería la segunda la más consistente. Lo que Nietzsche reclama de Wagner es que deje de simular un estilo totalizador que ya no es posible, que renuncie al anhelo de eternidad y acepte expresar la caducidad de valores y la crisis de sentido que acompaña a la experiencia histórica del nihilismo. Una vez que este inquietante huésped se ha infiltrado por todas las estancias de la Modernidad, advierte Nietzsche, una visión unitaria e idealizada de la realidad sólo puede darse como farsa y fingimiento. Es el mismo argumento por el que Zaratustra afirma que «los poetas mienten demasiado». Al encubrir el carácter de fictio del arte con otro falseamiento que trata de convertirlo en cifra de una verdad transcendente, se lo rebaja de hecho a una argucia técnica más.

Y aun así, Nietzsche no ha dejado de sugerir al mismo tiempo una posibilidad afirmativa para el arte wagneriano, coherente con su propio despojamiento de la máscara de la salud metafísica y el reconocimiento genealógico de su carácter de convaleciente de la gran enfermedad espiritual europea: el nihilismo; no ha dejado de apostar por una asunción activa de dicho arte como expresión de una realidad constitutivamente contradictoria, anunciando con ello una de las direcciones más estimulantes del arte contemporáneo ${ }^{48}$. Esta sugerencia se encuentra en el tercer epígrafe del capítulo de su obra Nietzsche contra Wagner,

46. Cf. $v$. g. los fragmentos KSA XIV 296-300: 14[119] y 14[120], y KSA XIV 356-357: $14[170]$.

47. M. Heidegger, Nietzsche, trad. cit., p. 93.

48. Para esta interpretación, me remito al trabajo de L. Crescenzi, «Grande stile e autoparodia. Friedrich Nietzsche e la fine dell'avanguardia», en G. Catalana y E. Fiandra (eds.), Ottocento tedesco, Napoli: La Città del Sole, 1998, pp. 343-369. 
titulado «Wagner como apóstol de la castidad», en el que Nietzsche se pregunta por el sentido de Parsifal y comenta:

¿Cómo? ¿Qué se ha tomado en serio este Parsifal? Porque, que se han reído de él, eso, yo, al menos, no podría discutirlo, ni tampoco Gottfried Keller... Sería de desear, en efecto, que el Parsifal de Wagner se tomase de forma jocosa, en cierto modo como una pieza conclusiva y un drama satírico, con el que el Wagner trágico hubiese querido despedirse de manera digna y decorosa de nosotros, de sí mismo y, sobre todo, de la tragedia, es decir, con un exceso de suprema y muy malévola parodia de lo trágico mismo, de toda la terrible seriedad y lamento terrenos de otro tiempo, de la más estúpida forma de contranaturaleza del ideal ascético, finalmente superada. Parsifal es un tema de opereta par excellence... (KSA VI 430; NW 201).

Naturalmente, al proponer esta lectura de Parsifal, es el propio Nietzsche quien está ironizando; pero no hay que obviar que lo hace a favor de una reapropiación positiva de la obra wagneriana. En cierto modo, pues, la crítica nietzscheana de madurez practica una estrategia similar a la empleada en su Intempestiva Richard Wagner en Bayreuth: allí se trataba de salvar a Wagner de los wagnerianos; ahora, se trata de salvar la obra de arte wagneriana de las veleidades romántico-cristianas del propio Wagner, reconduciendo la dirección del drama a un cuestionamiento de sus pretensiones metafísicas. Esta estrategia no está muy lejos del tipo de escritura filosófica practicada por Nietzsche, la cual no se limita a transmitir determinados contenidos epistémicos, sino que genera una distancia crítica con respecto a lo enunciado por ella y, como Zaratustra, «se comporta siempre paródicamente con los valores establecidos» (KSA XII 312).

Una vez se ha ingresado en el juego de este fabular consciente y paródico, quedan relativizadas las distintas posiciones, sin que ninguna pueda reclamar para sí el rango de verdad definitiva. Tal como sigue diciendo Nietzsche en el citado epígrafe:

¿Es el Parsifal de Wagner su secreta risa de superioridad sobre sí mismo, el triunfo de su última, suprema libertad de artista, de su ir más allá del artista? - ¿Es un Wagner que sabe reírse de sí mismo? Como he dicho, habría que desearlo, pues, ¿qué sería de Parsifal tomado en serio? Se tiene realmente necesidad de ver en él (como se ha dicho en contra mía) «el fruto de un odio furibundo hacia el conocimiento, el espíritu, la sensualidad»? ¿Una maldición sobre los sentidos y el espíritu en un mismo odio y un mismo aliento? ¿Una apostasía y una conversión hacia enfermizos y oscurantistas ideales cristianos? Y, en suma, ¿incluso un negarse a sí mismo, un tacharse-a-sí-mismo por parte de un artista que hasta entonces había pretendido lo contrario con todo el poder de su voluntad, la suprema espiritualización y sensualización de su arte? (KSA VI 430-431; NW 201).

Tanto si se toma en serio como si se toma a broma, Parsifal pone en entredicho la coherencia de la trayectoria intelectual de Wagner. En tanto ópera bufa y parodia de lo trágico, Parsifal desmiente las pretensiones idealistas del arte wagneriano. En tanto obra seria, supone un abandono de principios antaño defendidos por Wagner. En ambos casos, la ópera deja que salgan a escena las contradicciones por las que discurre el arte de Wagner y hace que éste, o 
bien se parodie a sí mismo como nuevo apóstol de la castidad o bien se niegue como antiguo paladín de la sensualidad. En el epígrafe anterior al pasaje citado, Nietzsche había comenzado afirmando que entre sensualidad y castidad no hay una oposición necesaria, que son precisamente estas contradicciones las que nos seducen y estimulan a vivir, manteniéndonos en un lábil equilibrio entre el ángel y la bestia. Esto es lo que él espera del arte venidero: que sea capaz de expresar la mutabilidad de la existencia, la imposibilidad de reducir el mundo a un único sentido, e ironice ante tales aspiraciones metafísicas.

Resulta innegable que Nietzsche ha trasladado a la controversia con Wagner su propio debate con dos formas de afrontar el nihilismo: pretendiendo superarlo con postulados que buscan una salvación externa a él, y que, pese a toda su crítica genealógica de la metafísica, aún parece resonar en proclamas como las de la gran salud o la gran política; o bien apurando a fondo las enseñanzas de esta enfermedad que hemos ido incorporando como elemento constitutivo de nuestra condición. El Nietzsche que explora esta segunda vía es el que he procurado mostrar aquí, pues es el que creo que más nos puede interesar y resultar más estimulante: ese que, por decirlo con las palabras de uno de sus más cualificados estudiosos, planteó problemas que aún no hemos resuelto, ese que tuvo el valor de mirar en las entrañas de nuestro tiempo, comprendiendo que la nueva fisonomía posmetafísica del mundo arrojaba al hombre a apurar las tensiones dentro de la finitud y le comprometía a una revalorización de las apariencias, sin el expediente de teleologías o sentidos impuestos de antemano. Incluso en sus paradojas y contradicciones, Nietzsche sigue teniendo así, para nosotros, el valor de un síntoma y de un contraste. Sintomático es, en efecto, que ya no nos escandalice el Nietzsche crítico del cristianismo, pero que siga irritándonos profundamente el Nietzsche crítico de la fe democrática. Mientras caen las bombas en cualquier remoto lugar, más allá de nuestro civilizado mundo, y se dice que esto se hace en nombre de la seguridad y libertad de la humanidad, ¿̇será que alguna otra de las viejas deidades del mundo occidental ha muerto y aún no nos hemos enterado? 